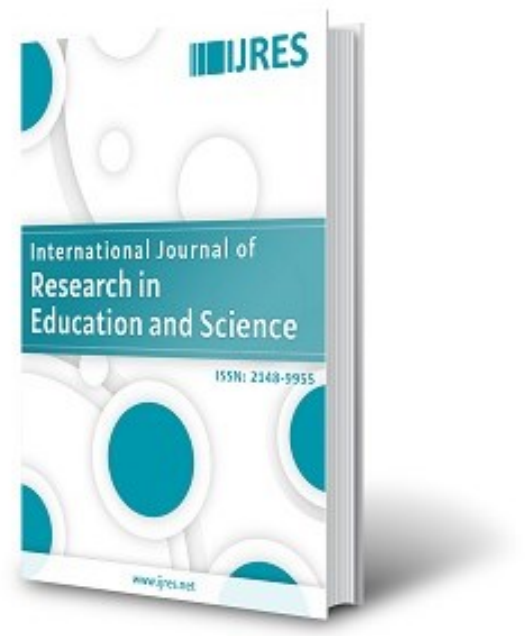

www.ijres.net

\section{Promoting Girls in Science - A Longitudinal Study of Self-Concept in Profile Classes}

\author{
Alena Schulte \\ Bielefeld University, Germany \\ Claas Wegner ic \\ Bielefeld University, Germany
}

.




\section{Promoting Girls in Science - A Longitudinal Study of Self-Concept in Profile Classes}

\begin{tabular}{|c|c|}
\hline \multicolumn{2}{|r|}{ Alena Schulte, Claas Wegner } \\
\hline Article Info & Abstract \\
\hline Article History & Previous studies show that girls have a lower scientific self-concept than boys. \\
\hline Received: & Since interest starts declining over the course of lower secondary school, this \\
\hline 04 March 2021 & exacerbates the issue that fewer girls aspire to choose a scientific profession. In \\
\hline Accepted: & this article we present the concent of scientific nrofile classes Profile classes \\
\hline 24 July 2021 & $\begin{array}{l}\text { pursue the goal of promoting girls by way of supporting their scientific self- } \\
\text { concept. A longitudinal study was conducted to examine the self-concept of } \\
\text { students in profile classes (Sample I } N=53 \text {; Sample II N=54). The development }\end{array}$ \\
\hline Keywords & of girls in profile classes was compared to both boys in profile classes and girls \\
\hline Profile classes & in the regular classes. Our results show that there is no gender difference in self- \\
\hline $\begin{array}{l}\text { Self-concept } \\
\text { Scientific-inquiry }\end{array}$ & concept between girls and boys in the profile class. This study provides initial \\
\hline Gender & indications of how girls in profile classes develop in terms of their self-concept. \\
\hline
\end{tabular}

\section{Introduction}

Germany is currently experiencing a shortage of skilled workers in the STEM sector according to the MINTHerbstreport, where scientists examine the scientific labor market twice a year (MINT-Herbstreport, 2019). This is already evident in the choice of studies in university; statistics show that of 2,891,049 students, only 322,086 chose a scientific subject. A gender gap accompanies this; more men study scientific subjects, especially in physics and chemistry (Federal Statistical Office, 2020).

Studies show that women have a more negative self-concept in science majors than men, despite equal performance (Ertl et al., 2017). This effect is already evident in lower secondary school, as this is when girls start to lose interest in science and science-related professions. They do not see themselves as capable of pursuing a science career (Kang et al., 2018; Todd \& Zvoch, 2019). Considering that, students already make decisions about their future career aspirations at the age of 12, it is even more important to foster interest and thus, self-concept (Lindahl, 2003; Maltese \& Tai, 2010). Recent studies show that scientific inquiry teaching promotes scientific interest, interest in scientific careers and self-concept (Kang \& Keinonen, 2017; Potvin \& Hasni, 2014). However, there have been few long-term studies to date that examine the relationship between scientific-inquiry teaching and self-concept in girls. By conducting a long-term study between $5^{\text {th }}$ and $7^{\text {th }}$ grade, we examined the extent to which scientific Profile Classes promote girls' self-concept during their school career, which may predict later career choices in science. 


\section{Theoretical Background}

\section{(Ability)Self-Concept}

Self-concepts are subjective beliefs about one's own abilities (Trautwein \& Möller, 2016). Existing definitions of self-concept emphasize its multidimensional structure. The theory according to Shavelson et al. (1976) is the most widely used. The authors have constructed a multidimensional, hierarchical and stable structure of selfconcept. The hierarchical structure describes self-concept, beginning with individual abilities in individual areas at the bottom and ending with general global self-concept at the top. Global self-concept is divided into two areas: academic and non-academic self-concept. Academic self-concept can be broken down into specific subject areas (e.g.: subjects). Non-academic self-concept is divided into social, emotional, and physical selfconcept (Shavelson et al., 1976).

Marsh et al. (1988) revised the hierarchical structure. According to Marsh et al. (1988), academic self-concept is divided into two equal-ranking domains: verbal and mathematical self-concept. The two self-concepts subdivide into further domains (e.g.: subjects). Verbal self-concept includes assessments of one's abilities in first and second languages, history, geography, etc. and mathematical self-concept is subdivided into scientific subjects (math, physics, chemistry, biology) (Marsh et al., 1988). Whether self-concept is hierarchical or dichotomous remains controversial (Trautwein \& Möller, 2016).

The present study is based on the model of Shavelson et al. (1976) and measures ability self-concept in science. Ability self-concepts, in the middle of the model, form a crucial factor to predict academic performance (Hannover \& Zander, 2020; see Figure 1).

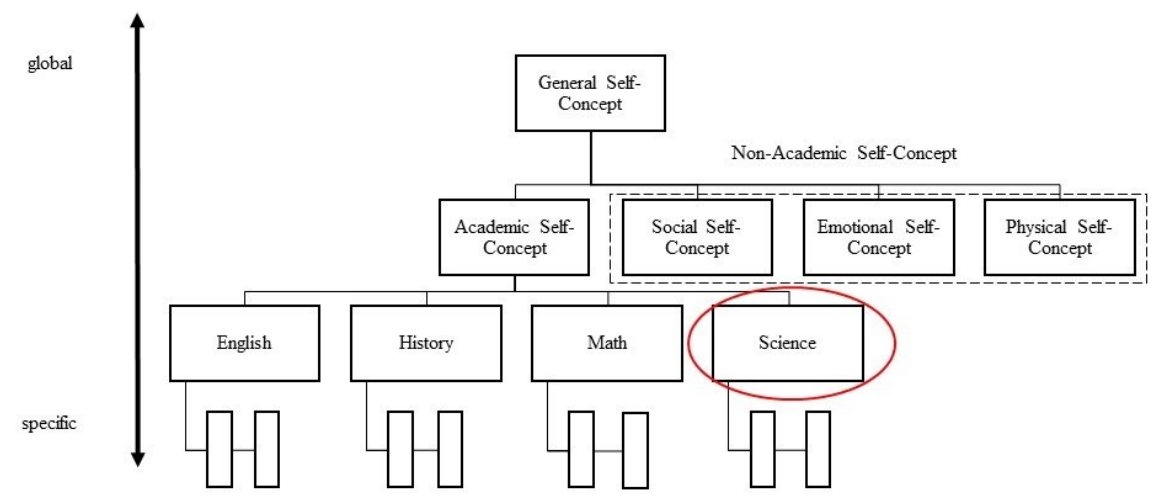

Figure 1. Hierarchical Structure of Self-Concept with a Focus on Domain-Specific Ability Self-Concept Highlighted in Red (modified after Shavelson et al., 1976, p. 413)

The development of self-concepts are influenced by various factors. Self-concept does not necessarily reflect the true abilities of a person, but are subjective assessments in a certain area (Trautwein \& Möller, 2016). Students compare their self-concept with others (social comparison), their previous performance (temporal comparison), and their abilities in other domains (dimensional comparison) (Wolff et al., 2018). These various comparisons can have different effects on a person's self-concept. 
Social comparison commonly goes hand-in-hand with the Big-Fish-Little-Pond-Effect (BFLPE) (Marsh, 1987). The BFPLE according to Marsh (1987) states that students with the same performance in high performing schools/classes have a lower self-concept than in lower performing schools/classes. This is accompanied by the fact that students would receive lower grades in a high-performing class than in a low-performing class, despite equal performance (Trautwein et al., 2006). High-performing learning environments appear to have a negative effect on self-concept but a positive effect on achievement (Dicke et al. 2018). However, no negative effects were found when gifted students were grouped in gifted classes or enrichment programs (Trautwein \& Möller, 2016). Enrichment as extracurricular activities can be added to the curriculum, such as study groups or school competitions (Preckel, 2008).

In a dimensional comparison, a student compares their performance/ability in one area/subject to the performance/ability in another subject (e.g., comparing math and German) (Trautwein \& Möller, 2016). Students who perform worse in mathematics than German tend to have a higher language self-concept than students who perform the same in German but have a higher mathematics self-concept (Möller et al., 2020; Trautwein \& Möller, 2016). This dimensional comparison is based on Marsh's (1986) internal/external frameof-reference model. According to this model, self-concept is the result of social and dimensional comparisons. Through a temporal comparison, a person compares their current performance/ability in a subject to their previous performance/ability in the same subject. The social, dimensional, and temporal comparison mechanisms occur simultaneously in the development of self-concept. Comparison mechanisms and selfconcept are further influenced by various factors (see Figure 2):

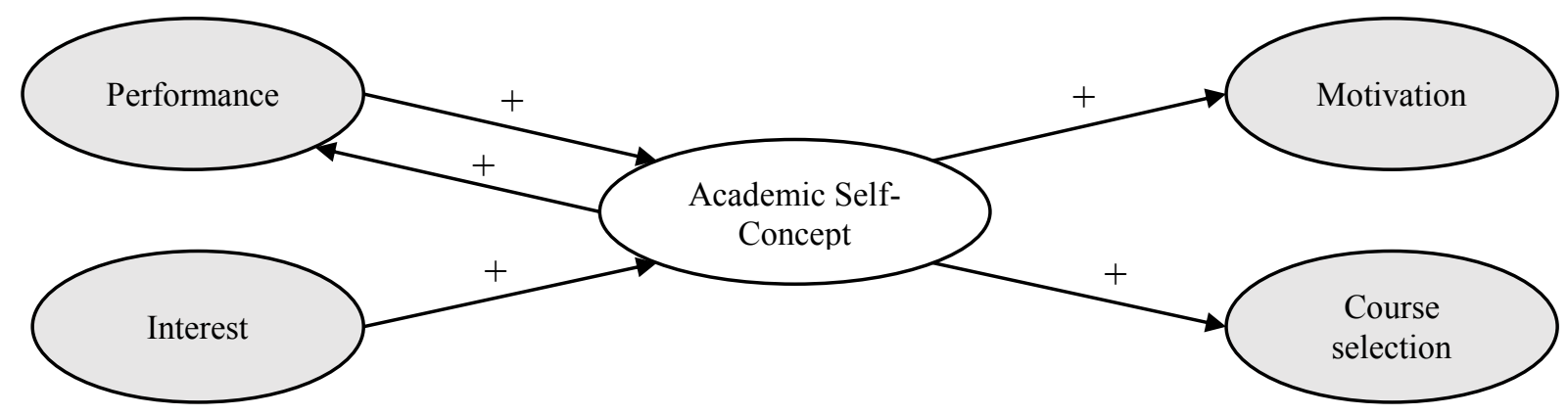

Figure 2. Effects of Predictors of Academic Self-Concept

According to Hannover and Zander (2020), many studies have shown that self-concepts predict performance. Long-term studies have shown that self-concept and performance reinforce each other. However, prior performance has a stronger effect on self-concept than the other way around. Positive self-concepts have a positive effect on motivation and performance because they are associated with high expectations of success or challenging goals. A person is more willing to put additional effort into an achievement, even if difficulties arise (Hannover \& Zander, 2020).

Students' interest in a particular area was also identified as another potentially relevant determinant of selfconcept. If students are interested in a particular area, they engage with it more often and acquire higher skills, which could have a positive effect on self-concept. The reciprocal relationship can conclude that a high self- 
concept in a domain may also promote a higher interest in that domain (Trautwein \& Möller, 2016). Furthermore, academic self-concept is a predictor of subsequent course and career selection. A high selfconcept in a particular area predicts course choice, field of study and career choice (Nagy et al., 2006; Simpkins et al., 2006).

The increase in students' self-confidence and their increased need for independence in adolescence is inconsistent with the classroom environment, which is characterized by high levels of control and the promotion of social comparison and competition in secondary schools. One way to promote self-concept in schools is for teachers to focus on temporal comparisons, rather than social comparisons, when providing performance feedback for students to better perceive their own development (Trautwein \& Möller, 2016).

\section{Ability Self-Concept in Science - Gender Differences}

Previous studies on gender differences in science indicate that boys rate their scientific self-concept higher than girls. On average, boys have a higher mathematical self-concept, whereas girls tend to have a higher linguistic self-concept (Trautwein \& Möller, 2016, Simpkins et al., 2006). These differences can be traced to stereotypical gender beliefs, among other factors. Bonnot and Croizet's (2007) study investigates whether women studying mathematics have internalized this stereotypical inferiority. Their results show that there are no gender differences in self-concept, the subjective value of math as a subject, or performance expectations. Nevertheless, the stereotypical image negatively affects women's ability self-concept and performance in math. Potvin and Hasni (2014) confirm in their systematic review that this gender difference becomes more "acute" with increasing age, and that prejudice/stereotypes are used as justifications for it.

Ertl et al. (2017) surveyed female students studying science subjects in which the proportion of women is below $30 \%$, to find out the extent to which family, school and individual prejudices influence a woman's academic self-concept. Although female students perform well in the science field, stereotypical prejudices affect their self-concept. The authors further demonstrate that girl's favourite subject in school has a positive influence on self-concept. It should be noted, however, that a specific lack of support at school and teacher prejudice could have a negative effect on self-concept. Special support at school in science could be understood as a compensation for a lack of skills in this area (Ertl et al., 2017).

Leibham et al. (2013) examined the relationship between an early interest in science (ages four \& six) and their later self-concept and science achievement (ages 8) in a longitudinal study. Boys show a higher interest in science than girls. Boys' interest did not influence the development of their own self-concept. For girls, early interest in science correlated with a higher self-concept at age 8 and predicted their science achievement. No significant differences in self-concept between genders were found in the age range between 4 - 8 years old (Leibham et al., 2013). Based on this, this study of girls' self-concept examines the extent to which interest in science influences girls' self-concept in Profile Classes. 
Scientific inquiry is one way to promote positive student attitudes toward science and scientific careers (Kang \& Keinonen, 2017). Students taught with an inquiry-based approach show a stronger interest in science and are more likely to report interest in science careers than students with a different focus in the classroom (Kang et al., 2018). Furthermore, in a study of $7^{\text {th }}$ graders from Finland, Kang et al., (2018) found a gender difference in interest in science subjects. In the study, girls preferred biology as a subject and boys preferred physics and chemistry. This effect has already been demonstrated in many other studies (Potvin \& Hasni, 2014; Gebhard et al., 2017). Kerger et al. (2011) demonstrated in their study (grades 8 and 9) that girls' interest in scientific topics was higher when they were included in female contexts. Similarly, boys' interest increases when topics are presented in masculine contexts. Female contexts are understood to be topics that have been empirically shown to promote girls' interest in science, for example biological issues (and vice versa for boys; e.g. technology, mechanics etc.). Simpkins et al. (2006) examined the associations between out-of-school activities and subject choices in math and science in a longitudinal study with 227 students from $5^{\text {th }}$ to $10^{\text {th }}$ grade. Results showed that out-of-school activities in 5th grade influenced their ability self-concept.

Students' self-concept and interest are theorized to be critical factors in later career choices. Students start thinking about career decisions at the beginning of lower secondary school (Schulte \& Wegner, 2021; Kang et al. 2018; Lindahl, 2003). Therefore, it is all the more important to promote girls' self-concept in science starting already in the lower grades. Deriving from the presented results, a teaching concept for profile classes emerges, which should consider the following factors:

- The possibility of differentiation and selection of gender-sensitive content (Hannover \& Zander, 2020; Kerger et al., 2011).

- Science study groups as a compulsory part of the teaching concept (Simpkins et al., 2006).

- Scientific inquiry, hands-on experiments, or researcher classes as the focus of lesson design and implementation (Ertl et al., 2017; Kang \& Keinonen, 2017).

- Women as role models for scientific professions (Ertl et al., 2017).

\section{Scientific Profile Classes}

As part of the development of school programs, schools often develop specific profiles. In general, school profiling is a process of school development initiated and implemented by the school itself (Altrichter et al., 2011). School profiles do not have a uniform concept. In general, a distinction is made between profiling individual classes and entire schools. Class profiling refers to individual classes that exist alongside regular classes. The creation of a profile can have the goal of promoting individual students and/or differentiating themselves from other schools in the same general location (ibid.). In Germany, profiles are mainly found at Gymnasien. Gymnasium is one of the three types of secondary schools students may choose after primary school. This school type allows students to take an entrance exam to later study at university. Due to the wide range of subjects, profiles can be implemented relatively easily and quickly (Klekovkin et al., 2015).

Scientific Profile Classes were established with the aim to foster students' interest and self-concept in lower grades. Students can attend the Profile Class from $5^{\text {th }}$ to $7^{\text {th }}$ grade. The teaching concept of these profile classes 
is characterized by a scientific focus. This is implemented both with additional teaching time in science per week (1 lesson) and with a mandatory extracurricular activity (Schulte \& Wegner, 2020). In addition to sciencefocused field trips, students at the schools can choose from a wide range of extracurricular science study groups. Profile Classes thus fulfil the requirement to integrate extracurricular activities into the concept (Simpkins et al., 2006). Topics in the Profile Classes are covered by the respective scientific curricula (Biology, Chemistry \& Physics). At each grade level, there is a new science focus in the specific lessons (see Figure 3).

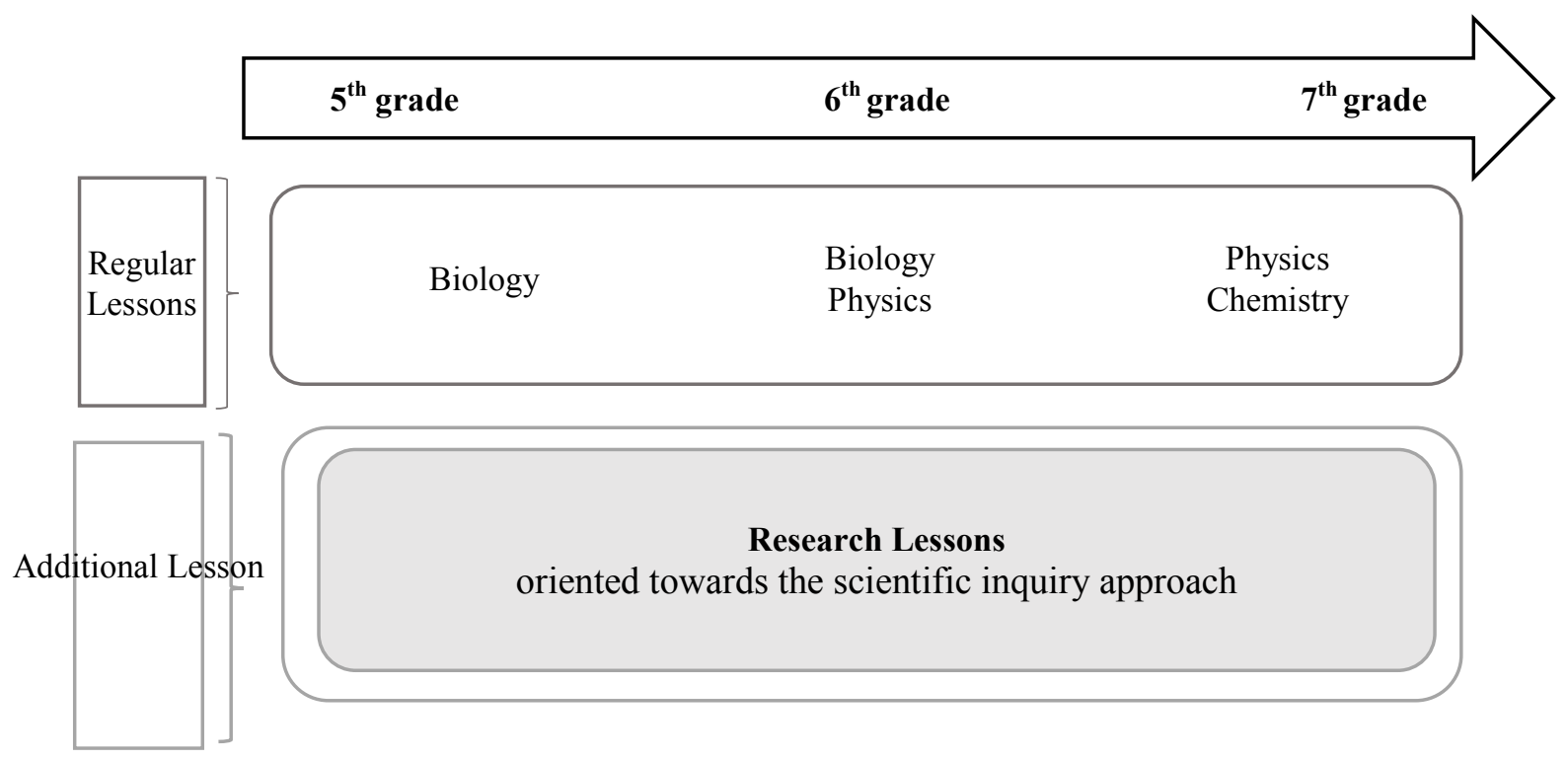

Figure 3. Model of Lessons in the Scientific Profile Class

The core curriculum of profile classes is flexible, so students can bring their own ideas and content into the classroom. Lessons focus on scientific research methods, especially on hypothesizing, observing and examining, planning and conducting experiments, working with models and microscopes, evaluating results and drawing conclusions. This inquiry-based approach is designed to foster positive student attitudes toward science (Kang \& Keinonen, 2017).

In additional lessons, students work out their own research questions, e.g.: "How do twins evolve?" or "What lives in the deep sea?". The questions are chosen and investigated by the students themselves and can arise from the respective scientific subject or from the students' everyday experiences. At the end of the semester, the results are presented in a research conference. The development of their own research questions should increase interest. In addition, the free choice of topics makes it possible to develop the content in female or male contexts and thus meets the demand for gender-sensitive teaching as described by Kerger et al. (2011). Ertl et al. (2017) also highlighted conducting experiments and research lessons as a possibility for gender-sensitive teaching. These teaching methods are used in the profile classes in this study. To date, the success of school profiling has been measured in terms of maintaining and/or increasing enrolment, perceived attractiveness of the school, and instructional development (Altrichter et al., 2011; Klekovkin et al., 2015). Profile classes, on the other hand, have hardly been evaluated in terms of long-term effects on students (Nonte, 2013). Previous studies on profile classes show that self-concept is a crucial influencing factor for choosing an elective at the end of $7^{\text {th }}$ grade 
(Schulte \& Wegner, 2021). The relevance here is that self-concept needs to be nurtured at a young age, as course choices/career decisions are made early on in middle school (Lindahl, 2003; Lyons, 2006; Simpson et al., 2015). The extent to which girls' self-concept in profile classes develops over the course of their school career will be examined in this study.

\section{Research Questions}

The current study investigated the development of ability self-concept and interest in girls that are in science Profile Classes between $5^{\text {th }}$ and $7^{\text {th }}$ grade. Therefore, two research questions were examined and their hypotheses (H1-H4) were posed:

- How does ability self-concept in science develop in Profile Classes for girls?

- Girls' self-concept increases between test times (H1).

- Girls' self-concept in Profile Classes is higher than boys' self-concept in Profile Classes (H2).

- Girls' self-concept in Profile Classes is higher than girls' self-concept in regular classes (H3).

○ What factors influence girls' ability self-concept in Profile Classes?

- Interest positively influences girls' ability self-concept in science (H4).

\section{Method}

Evaluating the profile classes is based on Shavelson et al. (2003) and allows us to accurately address this field of research and gain an overall understanding of teaching and learning in profile classes. Using this Design-Based Research approach, insights into the teaching-learning process can be gained in a specific practice context. This approach is divided into three main phases: the preliminary examination, the prototype development and the assessment (Klees \& Tillmann, 2015). The Profile Classes project is currently in the assessment phase. The lessons are tested several times and multiple evaluation methods are used to refine the approach based on new findings (see Figure 4).

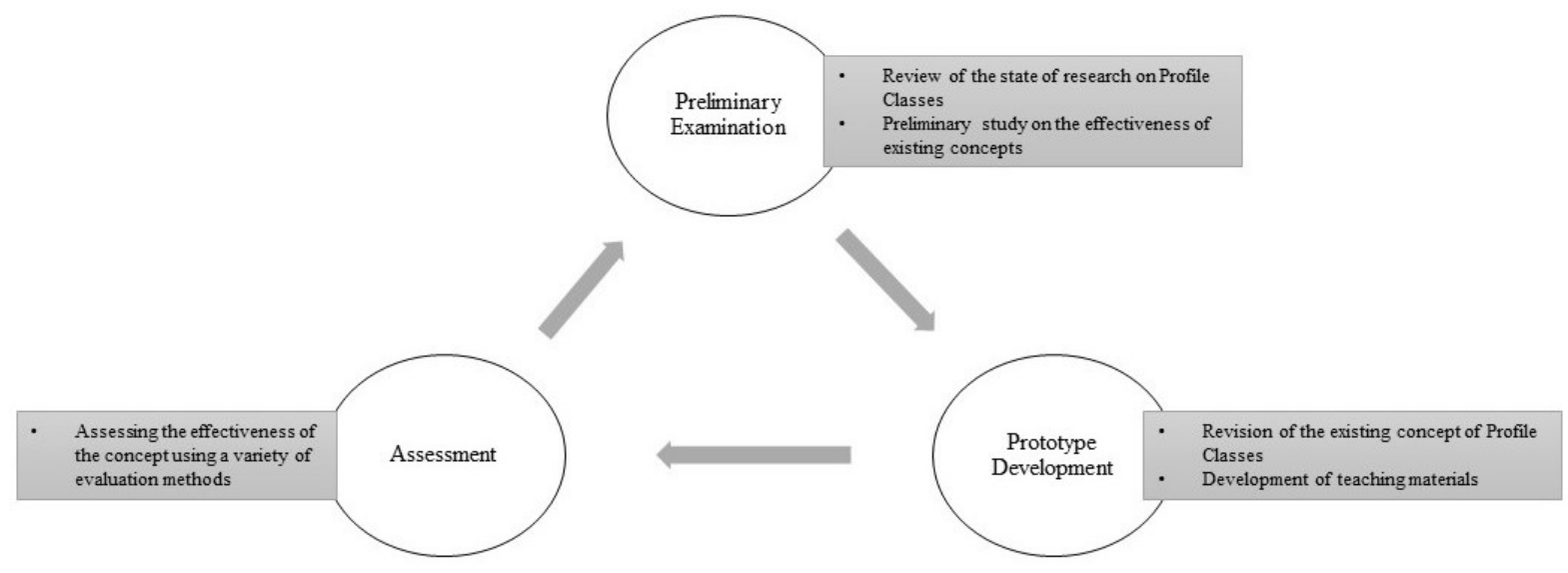

Figure 4. Design-Based-Research Approach in Profile Classes 
In the assessment phase, long-term effects of the scientific profile class on girls' ability self-concept will be examined. For this purpose, four classes will be examined more closely using a longitudinal study (see Figure 5).

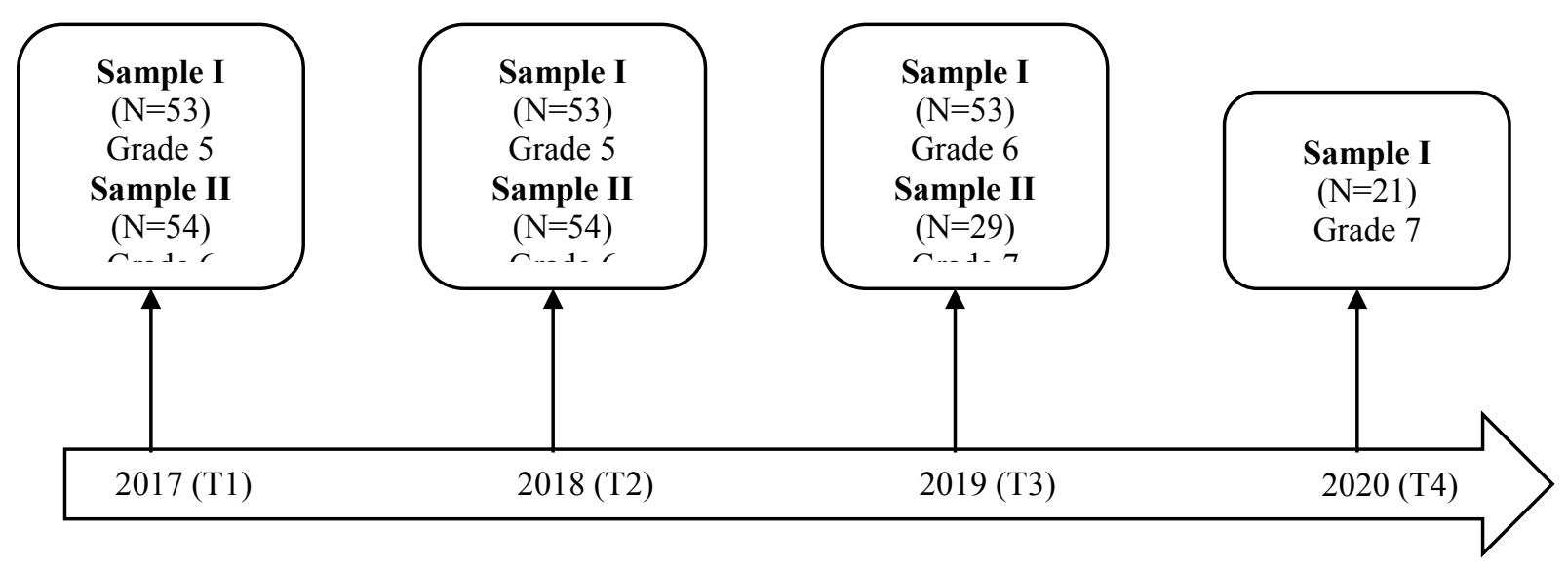

Figure 5. Survey Times of the Longitudinal Study in Profile and Regular Classes. The Grade is Indicated According to the Test Time

The two Classes in sample I ( $=53)$ have been continuously evaluated since 2017; since then, all students in Profile Classes were surveyed at four test times, and all students from the regular class were surveyed at three test times. At the beginning of the 2017 school year, students attended $5^{\text {th }}$ grade. The final survey took place in $7^{\text {th }}$ grade in 2020, where the students have finished the Profile Class and start to transition to the regular class in $8^{\text {th }}$ grade. The sample of regular class students could not be surveyed in 2020 due to the Covid-19 Pandemic. The two classes in sample II were also surveyed starting in 2017 , although these students were attending $6^{\text {th }}$ grade. In total, there were three test times of Profile and Regular Classes $(2017,2018,2019)$.

Students in both samples completed a questionnaire at all test times. Using a 6-point rating scale, students indicate their agreement with the constructs self-concept (very good - very bad) and interest (strongly agree strongly disagree). In addition, demographic data was recorded. Table 1 provides an overview of the constructs and their reliabilities at the individual test times.

Table 1. Example Items, Sources und Cronbach's-Alpha for the Constructs Self-Concept and Interest

\begin{tabular}{|c|c|c|c|}
\hline Construct & $\mathrm{N}$ & Example Item & Cronbach's Alpha $(\alpha)$ \\
\hline $\begin{array}{l}\text { Self-concept } \\
\text { (Hoffmann et al., 1998) }\end{array}$ & 7 & I understand concepts in the natural sciences & $\begin{array}{l}\text { T1: } 0,821 ; \text { T2: } 0,856 ; \\
\text { T3: } 0,871 ; \text { T4: } 0,838\end{array}$ \\
\hline $\begin{array}{l}\text { Interest } \\
\text { (Ferdinand, 2014; Frey, } \\
\text { 2009; Schreiner \& } \\
\text { Sjøberg, 2004). }\end{array}$ & 8 & $\begin{array}{l}\text { Natural science subjects in school are } \\
\text { interesting. }\end{array}$ & $\begin{array}{l}\text { T1: } 0,888 ; \text { T2: 0,909; } \\
\text { T3: 0,921; T4: } 0,947\end{array}$ \\
\hline
\end{tabular}




\section{Results}

\section{How does Girls' Ability Self-Concept in Science develop in Profile Classes?}

Development of the Self-Concept over Time

Sample I. Girls in profile classes had the highest self-assessment of self-concept at the beginning of the school period and the lowest in $6^{\text {th }}$ grade (see Figure 6). A Friedman test shows no significant differences in the selfconcept of girls in the profile classes over the course of the test times $\chi 2(3)=6.851, p=0.077, n=8)$.

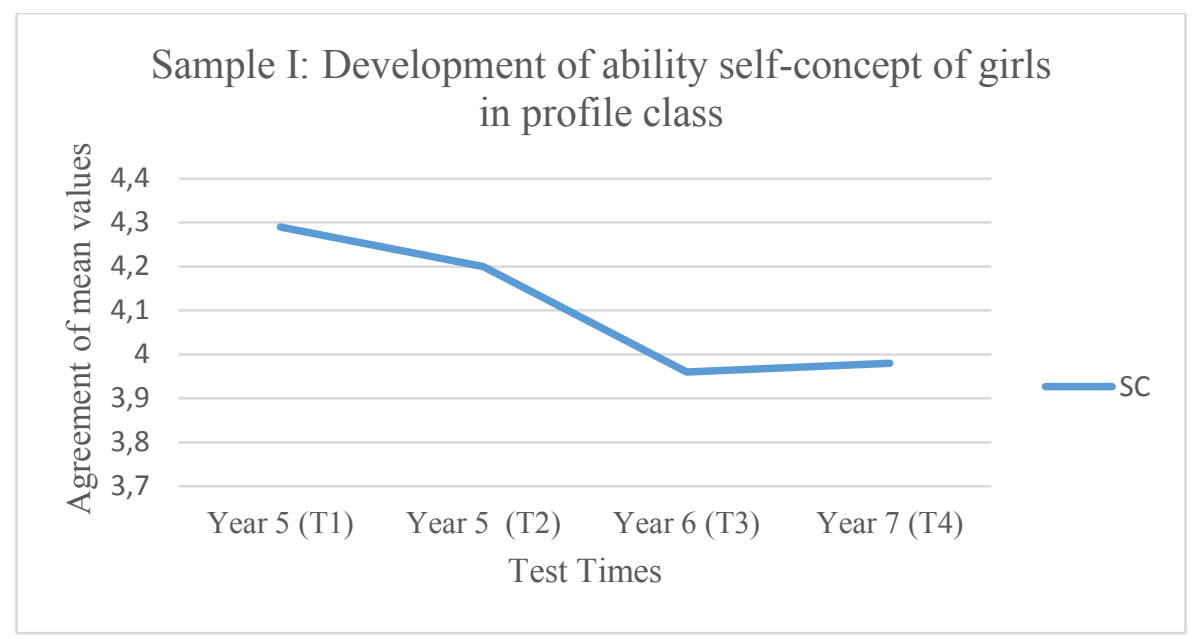

Figure 6. Sample I - Development of Self-concept in Girls within Profile Classes, between Test Times T1 - T4.

$$
\mathrm{SC}=\text { Ability Self-Concept; } \mathrm{n}=8 \text {. }
$$

Sample II. Self-assessment of girls from sample II is highest at the second test time point, which is at the end of $6^{\text {th }}$ grade (see Figure 7). The Friedman test shows significant differences in girls' self-concept between test times T2 and T3 $(\chi 2(2)=8.150, p=0.017, n=11)$ and a post-hoc Dunn-Bonferroni test confirms that these testing times significantly differ $\left(z=1,136, p_{\text {adjusted }}=.023\right.$, effect size according to Cohen (1992): $\left.r=.342\right)$. Test time 2 has the highest mean and test time 3 has the lowest.

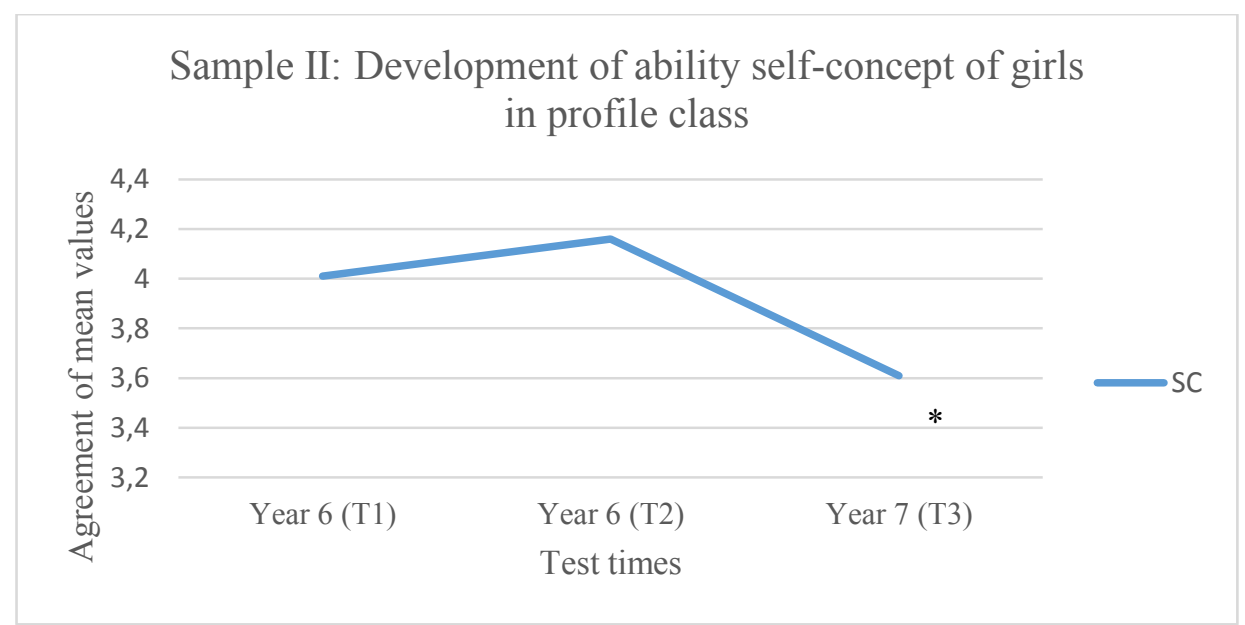

Figure 7. Sample II - Development of Self-concept in Girls within Profile Classes, between Test Times T1 - T3; $\mathrm{SC}=$ Ability Self-Concept; $\mathrm{n}=11$. Indication with Significance $(*) p \leq 0.01$. 
Gender Differences in Self-Concept Development

An repeated measures ANOVA with between-subjects factor gender found no significant gender difference between boys and girls in sample I (assumed sphericity: Mauchly-W(5) =.868, $p=.911 ; \mathrm{F}(3,36)=1.287, p=$ .293 , partial $\eta^{2}=.097$ ) or sample II (sphericity assumed: Mauchly-W(2) $=.835, p=.198 ; \mathrm{F}(2,38)=0.588, p=$ .560 , partial $\left.\eta^{2}=.030\right)$.

Differences of Girls in Profile and Regular Classes

Sample I. Three test times $(2017,2018,2019)$ were used to calculate differences between girls in the profile class and girls in the regular class. A repeated measures ANOVA and between-subjects factor class (sphericity assumed: Mauchly-W(2) $=.981, p=.822$ ) showed a statistically significant interaction between time and class $\left(\mathrm{F}(2,42)=3.514, p=.039\right.$,partial $\eta^{2}=.143$; effect size: .408$)$.

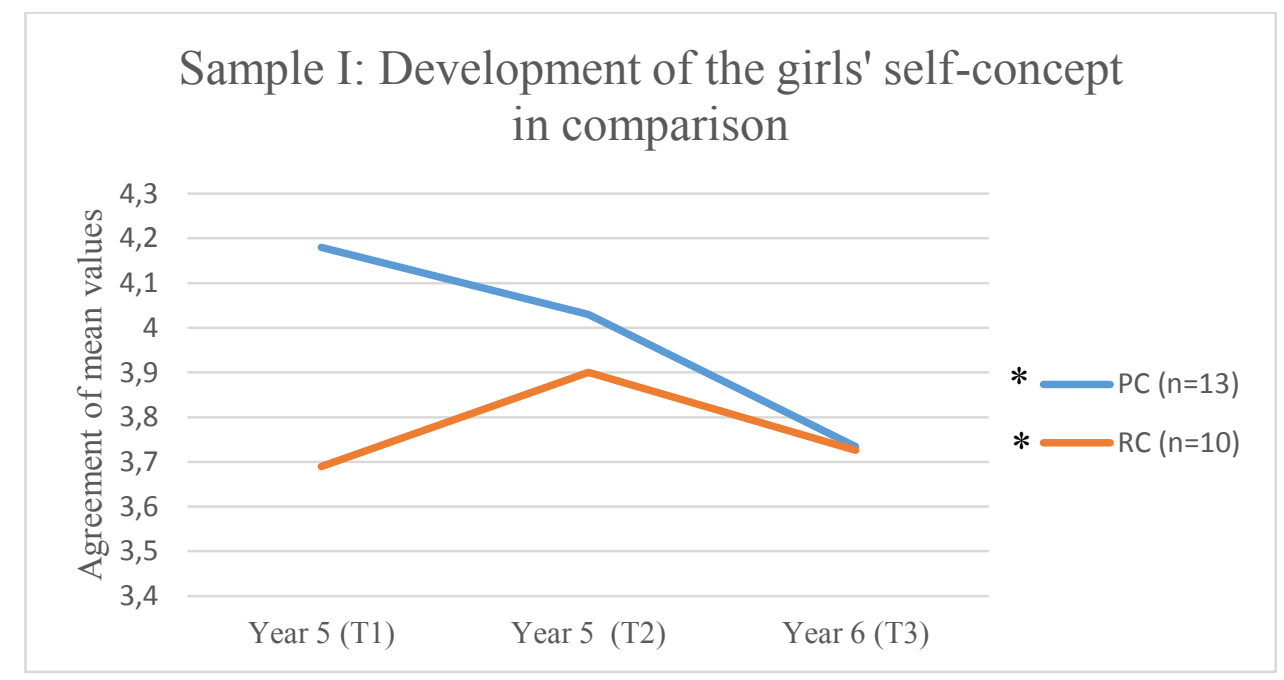

Figure 8. Sample I - Development of Self-concept for Girls in the Profile Class and Girls in the Regular Class between Test Times T1 - T3.; PC = Profile Class; RC = Regular Class, $\mathrm{N}=23$.

Indication with Significance $(*) \mathrm{p} \leq 0.05$.

Girls in the profile class $(\mathrm{M}=4.23, \mathrm{SD}=0.54)$ showed a significantly higher self-concept at the first test time than girls in the regular class $(\mathrm{M}=3.68, \mathrm{SD}=0.55)(\mathrm{t}(24)=-2,501, p=.020$; effect size: .35). Over time, the mean values converged and are approximately equal at the third time point.

Sample II. In the second sample, a repeated measures ANOVA and between-subjects factor class did not detect a significant interaction between time and class $(\mathrm{F} 1,23)=1.593, p=.220$, partial $\left.\eta^{2}=.065\right)$.

\section{What Factors influence Girls’ Ability Self-Concept in Profile Classes?}

At three test times, the influence of interest in girls taking profile classes was calculated using a multiple regression (independent variables are interest and year). 
1. Test time (2017). A multiple regression analysis shows that the model as a whole is significant $(\mathrm{F}(2,25)=$ 9.907, $p=.001, n=28)$. The $\mathrm{t}$-test for the regression coefficient interest $(\mathrm{t}=4.195, p=.000)$ is significant. If self-concept increases/decreases by one unit, then interest increases/decreases by .640. The corrected R-squared is .398 , which means that $39.8 \%$ of the total variance of the overall result is explained by interest. The effect strength of 0.66 corresponds to a strong effect.

2. Test time (2018). At the second test time point, a multiple regression $\mathrm{F}(2,26)=3.601, p=.042, \mathrm{n}=29)$ shows that the $\mathrm{t}$-test for the regression coefficient interest $(\mathrm{t}=2.656, p=.013)$ is significant. If self-concept increases/decreases by one unit, then interest increases/decreases by .249. The corrected R-squared is .157, which means that $15.7 \%$ of the total variance of the overall result is explained by interest. The effect size of 0.19 corresponds to a medium effect.

3. Test time (2019). A multiple regression at the third test time $(\mathrm{F}(2,22)=5.013, p=.016, n=25)$ shows a significant regression coefficient interest $(\mathrm{t}=3.159, p=.005)$. If self-concept increases/decreases by one unit, then interest increases/decreases by .468 . The corrected R-squared is .251 , which means that $25 \%$ of the total variance of the overall result is explained by interest. The effect size of 0.34 corresponds to a medium effect.

\section{Discussion}

\section{Research Question I}

The development of ability self-concept over time differs in both samples. An increase in self-concept from girls in the profile classes is only observed between certain test times (sample I: T3 - T4; sample II: T1 - T2). At the same time, self-concept decreases between the other test times. These results lead to the conclusion that the hypothesis (H1: Girls' self-concept increases between test times) must be rejected.

The girls in profile classes and the girls in regular classes from sample I showed the lowest self-concept in the $6^{\text {th }}$ grade. One explanation could be the subject matter, as studies show that girls are not very interested in physical science topics (Potvin \& Hasni, 2014). Ertl et al. (2017) demonstrated that having a favourite subject is a positive predictor of self-concept. Therefore, a negative association with the subject physics in this sample may have a negative effect on girls' self-concept. This negative effect is still seen in profile classes even though they can generate and investigate their own research question. Another factor that can potentially influence selfconcept is their teacher. Teachers can support interest and the development of a positive self-concept, allowing students to have positive experiences in science subjects (Ertl et al., 2017). In contrast, the girls in Sample II showed the highest self-assessment of self-concept at the second test time. Here, the subject of physics does not seem to have a negative influence on self-concept; instead, the $6^{\text {th }}$ grade leads to a slight increase in the girls' self-concept.

This is in contrast to the girls' self-assessment in profile classes between $6^{\text {th }}$ and $7^{\text {th }}$ grade. In Sample I, their selfassessment increases slightly, and the inverse is seen in sample II. It should be noted that at the end of $7^{\text {th }}$ grade in Sample I in 2020, it is likely that only motivated and interested female students continued to participate in the 
survey. Since schools were closed due to the coronavirus, the survey was conducted digitally. In March 2020, schools were closed because of the worldwide pandemic (Ministerium für Schule und Bildung des Landes Nordrhein-Westfalen, 2020).

Studies show that self-concept assessment declines between school entry and adolescence (between $1^{\text {st }}$ and $9^{\text {th }}$ grade) (Potvin \& Hasni, 2014). Self-concept is thought to stabilize at approximately 15 years old. This could explain the drop in self-concept in profile classes. Furthermore, this decrease does not suggest a low selfconcept in all subjects; students may show differentiated self-concepts in different school subjects (Trautwein \& Möller, 2016).

There are no differences between genders in either Sample I or Sample II. The hypothesis that girls assess themselves better than boys can therefore be rejected $(\mathrm{H} 3)$. This result is confirmed by other studies (Leibham et al., 2013). The girls in the profile classes rate their self-concept similarly to the boys. Profile classes seem to promote both genders. Complementary to this finding, no gender differences in the regular classes could be demonstrated in both samples. However, the boys' self-assessment is partly higher than the girls' selfassessment; this descriptive difference is not significant.

A comparison of girls in the profile classes and girls in the regular class shows different results in the samples (H3). In Sample II, the girls' affiliation with the profile class or the regular class has no influence on the development of their self-concept. In contrast, class affiliation in Sample I has a significant impact on selfconcept. Looking at this result more closely, it should be noted that the girls in the profile classes have a significantly higher self-concept at the beginning. However, by the end of the $6^{\text {th }}$ grade, the mean scores of both groups equalize. It should be noted here that the girls in the profile classes show the lowest self-assessment of self-concept at this time and that this increases by the last test time in $7^{\text {th }}$ grade. A comparison with $7^{\text {th }}$ grade is missing and would have to be completed for a final evaluation of the hypothesis. Based on these results, however, initial indications can be given as to how self-concept of girls in profile classes develops over time.

\section{Research Question II}

Interest influences self-concept in both classes at all test times, regardless of the year (confirms H4). If selfconcept decreases/increases by one unit, then interest also decreases/increases. The higher/lower the selfassessment of self-concept, the higher/lower the interest in science. Interest as a positive predictor of selfconcept has already been confirmed in many other studies (Leibham et al., 2013; Lindahl, 2003; Hannover \& Zander, 2020).

This positive correlation indicates that promoting self-concept in relation to scientific interest is worthwhile. Nevertheless, it should be noted that self-concept is not stable over time and can decrease. As interest in science classes declines, self-concept will also decline. Krapp et al. (2014), also highlight this relationship. Ability selfconcept includes information related to oneself, such as interest in certain content (ibid.). If either aspect is promoted, interest or assessment of ability self-concept also increases. 
One teaching method to encourage interest in science is scientific inquiry (Kang \& Keinonen, 2017). This approach promotes interest as well as career choice. Students with an inquiry approach are more likely to choose a scientific subject than students without this approach (Kang et al., 2018). Especially with the current shortage of skilled workers, it is essential to get students interested in scientific careers at an early age (Lindahl, 2003). Profile classes are a good opportunity to encourage students to become interested in science. Scientific inquiry should not only be implemented within the additional teaching time but also in regular profile class lessons. The profile class curriculum was adapted for regular lessons based on these results. In addition, more gendersensitive topics should be added to the curriculum (Kerger et al., 2011; Hannover \& Zander, 2020). The compulsory curriculum in regular lessons has been supplemented by additional topics that go beyond the normal content of the lessons. This is intended to differentiate Profile class lessons from those in regular classes. Based on the student interests, the teacher can decide on content, which could be studied in greater depth. For example, the new curriculum includes expert interviews with a beekeeper, excursions to a stream, or the independent development of experiments on an issue ("Which body shape is the fastest swimmer?").

\section{Conclusions}

One limitation of this study is the small sample size. Increasing the sample size could help clarify the contrasting assessment of self-concept in 6th grade by surveying more girls and more regular classes. In summer 2021, the sample will be increased. For self-assessments of self-concept, the survey asks about both the scientific subjects in each grade and the additional teaching time used as research lessons. Separating profile class lessons and the additional time students are given within the survey could provide further conclusions regarding self-concept. Only then can it be evaluated whether teaching in the profile classes' favours genderappropriate promotion of self-concept. Performance was not considered as a predictor in this study because the sample size was too small. In further studies, this factor should be considered as it has been shown that achievement and self-assessment are related (Hannover \& Zander, 2020). Although the sample size is small, this study contributes to the potential of using open-ended, research-based approaches to increase girls' self-concept in profile classes.

\section{References}

Altrichter, H., Heinrich, M., \& Soukup-Altrichter, K. (2011). Schulentwicklung durch Schulprofilierung? Zur Veränderung von Koordinationsmechanismen im Schulsystem. Wiesbaden: VS Verlag für Sozialwissenschaften / Springer Fachmedien Wiesbaden GmbH, Wiesbaden. doi: 10.1007/978-3-53192825-8

Bonnot, V. \& Croizet, J-C. (2007). Stereotype Internalization, Math Perceptions, and Occupational Choices of Women with Counter-Stereotypical University Majors. Swiss Journal of Psychology, 66(3), 169-178. doi: 10.1024/1421-0185.66.3.169

Cohen, J. (1992). A power primer. Psychological Bulletin, 122(1), 155-159.

Dicke, T., Parker, P., Guo, J., Marsh, H., Pekrun, R., \& Televantou, I. (2018). Effects of school-average achievement on individual self-concept and achievement: Unmasking phantom effects masquerading as 
true compositional effects. Journal of Educational Psychology, 110(8), $1112 \quad$ - 1126. https://doi.org/10.1037/edu0000259

Ertl, B., Luttenberger, S. \& Paechter, M. (2017). The Impact of Gender Stereotypes on the Self-Concept of Female Students in STEM Subjects with an Under-Representation of Females. Frontiers in Psychology, 8(703), 1-11. doi: 10.3389/fpsyg.2017.00703

Ferdinand, H. (2014). Entwicklung von Fachinteresse: Längsschnittstudie zu Interessenverläufen und Determinanten positiver Entwicklung in der Schule. Münster [u.a.]: Waxmann

Frey, A. (Ed). (2009). PISA-2006-Skalenhandbuch. Münster [u.a.]: Waxmann.

Gebhard, U., Höttecke, D., \& Rehm, M. (2017). Pädagogik der Naturwissenschaften. Wiesbaden: Springer Fachmedien. 10.1007/978-3-531-19546-9

Hannover, B., \& Zander, L. (2020). How Personal and Social Selves Influence the Development of Children and Adolescents at School. Zeitschrift für Pädagogische Psychologie, 34(2), 65-85. https://doi.org/10.1024/1010-0652/a000261

Hoffmann, L., Häußler, P., \& Lehrke, M. (1998). Die IPN-Interessenstudie Physik. IPN: Kiel.

Institut der deutschen Wirtschaft (2019). MINT-Herbstreport 2019. Retrieved from: https:/www.iwkoeln.de/studien/gutachten/beitrag/christina-anger-oliver-koppel-axel-pluennecke-ennoroeben-ruth-maria-schueler-basis-zur-zukunftssicherung-durch-forschung-und-digitalisierung.html

Kang, J. \& Keinonen, T. (2017). The effect of inquiry-based learning experiences on adolescents ${ }^{\star}$ science $^{-}$ related career aspiration in the Finnish context. International Journal of Science Education, 39(12), 1669-1689. doi: 10.1080/09500693.2017.1350790

Kang, J., Hense, J., Scheersoi, A., \& Keinonen, T. (2018). Gender study on the relationships between science interest and future career perspectives. International Journal of Science Education, 41(1), 80-101. doi: 10.1080/09500693.2018.1534021

Kerger, S., Martin, R. \& Brunner, M. (2011). How can we enhance girls' interest in scientific topics? British Journal of Educational Psychology, 81, 606-628. doi: 10.1080/09500693.2017.1350790

Klees, G. \& Tillmann, A. (2015). Design-Based Research als Forschungsansatz in der Fachdidaktik Biologie. Journal für Didaktik der Biowissenshaften, 6, 91 - 110.

Klekovkin, T., Nonte, S., \& Stubbe, T. C. (2015). Die Verbreitung von Schul- und Klassenprofilen an weiterführenden Schulen in Hamburg und Regierungsbezirk Braunschweig in Niedersachsen. (Working Paper No. 1 des Lehrstuhls Schulpädagogik / Empirische Schulforschung der Georg-August-Universität Göttingen). $\quad$ Retrieved from: http://www.publikationen.stubbe.info/Klekovkin_Nonte_Stubbe_2015_DVvSuK.pdf

Krapp, A., Greyer, C., Lewalter, D. (2014). Motivation und Emotion. In Fritz, A., Hussy, W., Tobinski, D. (Eds.) Pädagogische Psychologie. (pp.193-222) 6. Auflage, Weinheim u.a.: Beltz.

Leibham, M. B., Alexander, J. M. \& Johnson, K. E. (2013). Science Interests in Preschool Boys and Girls: Relations to Later Self-Concept and Science Achievement. Science Education, 97(4), 574-593. doi: $10.1002 /$ sce. 21066

Lindahl, B. (2003). Pupils' responses to school science and technology? A longitudinal study of pathways to upper secondary school. English summary of a dissertation. Retrieved From: 
https://www.researchgate.net/publication/237722627_Pupils'_responses_to_school_science_and_technol ogy_A_longitudinal_study_of_pathways_to_upper_secondary_school

Lyons, T. (2006). Different Countries, Same Science Classes: Students' experiences of school science in their own words. International Journal of Science Education, 28(6), 591-613. doi: $10.1080 / 09500690500339621$

Maltese A., \& Tai, R. (2010). Eyeballs in the Fridge: Sources of early interest in science. International Journal of Science Education, 32(5), 669-685. Doi: 10.1080/09500690902792385

Marsh, H. W. (1986). Verbal and math self-concepts: An internal/external frame of reference model. American Educational Research Journal, 23(1), 129-149.

Marsh, H. W. (1987). The Big-Fish-Little-Pond effect on academic self-concept. Journal of Educational Psychology, 79(3), 280-295.

Marsh, H. W., Byrne, B. M., \& Shavelson, R. J. (1988). A multifaceted academic self-concept: Its hierarchical structure and its relation to academic achievement. Journal of Educational Psychology, 80(3), 366-380.

Ministerium für Schule und Bildung des Landes Nordrhein-Westfalen (2020). Umgang mit dem Coronavirus an Schulen. Retrieved from: https://www.schulministerium.nrw.de/ministerium/schulverwaltung/schulmailarchiv/archiv-2020/13032020-umgang-mit-dem-corona-virus

Möller, J., Zitzmann, S., Helm, F., Machts, N., Wolff, F. (2020). A Meta-Analysis of Relations Between Achievement and Self-Concept. Review of Educational Research, 90(3), 376-419. Doi: $10.3102 / 0034654320919354$

Nagy, G., Trautwein, U., Baumert, J., Köller, O., \& Garrett, J. (2006). Gender and course selection in upper secondary education: Effects of academic self-concept and intrinsic value. Educational Research and Evaluation, 12, 323-34.

https://doi.org/10.1080/13803610600765687

Nonte, S. (2013). Entwicklungen und Auswirkungen der Schulprofilierung an allgemeinbildenden Schulen in ausgewählten europäischen Ländern und Implementationsperspektiven für Deutschland. International Review of Education, 59(2), 243-262. Doi: 10.1007/s11159-013-9357-1

Schreiner, C. \& Sjøberg, S. (2004). Sowing the seeds of ROSE. Background, Rationale, Questionnaire Development and Data Collection for ROSE (The Relevance of Science Education) - a comparative study of students' views of science and science education (pdf) (Acta Didactica 4/2004). Oslo: Dept. of Teacher Education and School Development, University of Oslo

Schulte, A. \& Wegner, C. (2020). Science-Klassen - Wie gelangt naturwissenschaftliche Förderung in die Schulen? MNU Journal, 73 (4), 309-312.

Schulte, A. \& Wegner, C. (2021). Choosing an elective - What impact do scientific profile classes have? Progress in Science Education (PriSE), 4(1), 5-10.

Shavelson, R. J., Hubner, J. J., \& Stanton, G. C. (1976). Self- Concept: Validation of construct interpretations. Review of Educational Research, 46(3), 407-441.

Shavelson, R. J., Phillips, D. C., Towne, L. \& Feuer, M. (2003). On the Science of Education Design Studies. Educational Researcher, 32(1), 25-28. 
Simpkins, S. D., Davis-Kean, P. E., \& Eccles, J. S. (2006). Math and science motivation: A longitudinal examination of the links between choices and beliefs. Developmental Psychology, 42(1), 70-83. doi: 10.1037/0012-1649.42.1.70

Simpson, A., Che, S. M. \& Bridges, W. C. (2015). Girls' and Boys' Academic Self-Concept in Science in Single-Sex and Coeducational Classes. International Journal of Science \& Mathematics Education, 14, 1407-1418. doi: 10.1007/s10763-015-9676-8

Statistisches Bundesamt (Federal Statistical Office) (2020). Studierende nach Fächergruppen. Abgerufen von: https://www.destatis.de/DE/Themen/Gesellschaft-Umwelt/Bildung-Forschung-

Kultur/Hochschulen/Tabellen/studierende-insgesamt-faechergruppe.html.

Todd, B. L. \& Zvoch, K. (2019). The effect of an informal science intervention on middle school girls' science affinities. International Journal of Science Education, 41(1), 102-122. doi: 10.1080/09500693.2018.1534022

Trautwein, U., Lüdtke, O., Marsh, H. W., Köller, O., \& Baumert, J. (2006). Tracking, grading, and student motivation: Using group composition and status to predict self-concept and interest in ninth grade mathematics. Journal of Educational Psychology, 98(4), 788-806. doi: 10.1037/0022-0663.98.4.788

Trautwein, U., \& Möller, J. (2016). Self-Concept: Determinants and Consequences of Academic Self-Concept in School Contexts. Lipnevich, A., Preckel, F., Roberts, R. D. (Eds.). Psychosocial Skills and School Systems in the $21^{\text {st }}$ Century. Switzerland: Springer International Publishing, 187-214. doi: 10.1007/978-3319-28606-8

Potvin, P. \& Hasni, A. (2014). Interest, motivation and attitude towards science and technology at K-12 levels: a systematic review of 12 years of educational research. Studies in Science Education, 50(1), 85-129. doi: $10.1080 / 03057267.2014 .881626$

Preckel, F. (2008). Erkennen und Fördern intellektuell hochbegabter Schülerinnen und Schüler. Petermann, F: (Ed.). Angewandte Entwicklungspsychologie. Göttingen [u.a.] Hogrefe

Wolff, F., Helm, F., Zimmermann, F., Nagy, G., \& Möller, J. (2018). On the effects of social, temporal, and dimensional comparisons on academic self-concept. Journal of Educational Psychology, 110(7), 1005 1025. doi: http://dx.doi.org/10.1037/edu0000248

\section{Author Information}

\begin{tabular}{ll}
\hline Alena Schulte & Claas Wegner \\
(iD) https://orcid.org/0000-0002-5075-9942 & iD https://orcid.org/0000-0001-8866-7704 \\
Bielefeld University & Bielefeld University \\
Department for Didactics of Biology & Department for Didactics of Biology \\
Universitätsstraße 25, 33615 Bielefeld & Universitätsstraße 25, 33615 Bielefeld \\
Germany & Germany \\
Contact e-mail: alena.schulte@uni-bielefeld.de & \\
\hline
\end{tabular}

